\title{
TRADITIONAL TOPICS FOR THE FRAMEWORK EDUCATIONAL PROGRAMME FOCUSED ON ICT AREA, AND THE PERCEPTION OF THESE TOPICS BY THE PRIMARY SCHOOL NINTH GRADE PUPILS
}

Milan KLEMENT*, Univerzita Palackého v Olomouci, Česká republika

Přijato: 13. 4. 2018 / Akceptováno: 8. 7. 2018

Typ článku: Teoretická studie

DOI: $10.5507 /$ jtie.2018.003

Abstract: What does the specific educational content of IT subjects at lower and upper primary schools look like? What computer related topics are actually taught? Are there any topics which are not embedded or accentuated in the current curriculum documents? We shall try to answer these questions in the submitted paper, which presents partial outputs of the conducted research, primarily focused on the issue of the acceptance of the educational content of IT subjects taught at primary schools in the Czech Republic, with special attention to the 9th grade pupils.

Key words: Information Technology, IT reated school subjects, educational content.

\section{TRADIČNÍ A NETRADIČNÍ TÉMATA RVP PRO OBLAST INFORMAČNÍ A KOMUNIKAČNÍ TECHNOLOGIE A JEJICH REFLEXE ZE STRANY ŽÁKŮ 9. TŘÍD ZÁKLADNÍCH ŠKOL}

Abstrakt: Jak vypadá konkrétní vzdělávaci obsah informatických predmètů na 1. a 2. stupni českých základních škol? Která informatická témata jsou ve skutečnosti vyučována? Objevuji se ve výuce i témata, která nejsou v rámci platných kurikulárnich dokumentů zakotvena či príliš akcentována? Na tyto otázky se pokusime odpovédět v rámci předložené stati, ve které jsou uvedeny některé dílči výstupy realizovaného výzkumného šetření, které bylo primárně zaměreno na problematiku akceptace výukového obsahu informatických předmětů, vyučovaných na základních školách v České republice, a jehož cílovou skupinou tvořili žáci 9. tř́d.

Klíčová slova: informatika, informatické předměty, vzdělávací obsah.

*Autor pro korespondenci: milan.klement@upol.cz 


\section{1 Úvod}

Potřeba inovace obsahu vzdělávání v rámci výuky Informatiky, respektive informatických předmětů, v podmínkách českých základních a středních škol je dnes relativně velmi hojně diskutované téma. Nicméně samotné kurikulum informatických předmětů v České republice však výraznějším změnám stále odolává. Vzdělávací obsah, a stejně tak i vyučovací metody informatických předmětů na základních školách, zůstávají léta víceméně beze změn. Jiná situace je ale pozorovatelná v zahraniční, kde se již řadu let zabývají přední odborníci prostř̌ednictvím různých summitů, organizací a federací (WSIS, ACM, IFIP, UNESCO) ${ }^{1}$, návrhy na změnu koncepce výuky tak, aby žáci nebyli vychováváni pouze $\mathrm{v}$ aktivní uživatele technologií, jejich softwarových nástrojů a v „konzumenty“ digitálního obsahu, ale aby se sami snažili vymýšlet vlastní postupy, navrhovat nástroje k řešení konkrétních problémů a rozvíjet tzv. informatické myšlení.

V souvislosti s těmito snahami se tedy objevil pojem informatické myšlení (computational thinking). Jde o relativně nový pojem (Lessner, 2014), který odráží potřebu porozumění světu kolem nás z nové perspektivy, tedy z pohledu informací a způsobů, jakými fungují digitální technologie. Jde o způsob uvažování, který používá informatické metody řešení problémů, a to včetně problémů komplexních či nejasně zadaných. Rozvíjí schopnost analyzovat a syntetizovat, zevšeobecňovat, hledat vhodné strategie řešení problémů a ověřovat je $\mathrm{v}$ praxi. Vede $\mathrm{k}$ přesnému vyjadřování myšlenek a postupů a jejich zaznamenání ve formálních zápisech, které slouží jako všeobecný prostředek komunikace. Pracuje se základními univerzálními pojmy, které přesahují současné technologie: algoritmus, struktury, reprezentace informací, efektivita, modelování, informační systémy, principy fungování digitálních technologií (viz Strategie digitálního vzdělávání do roku $2020^{2}$ ).

Všechny tyto skutečnosti implikují potřebu integrace digitálních technologií a rozvoje digitálních kompetencí ve spojení s rozvojem kritického a tvưrčího myšlení, které navazuje na schopnost aktivního řešení problémů, informatického myšlení a kreativity do vzdělávacího obsahu a vzdělávacího procesu (Štípek a kol, 2015; Ala-Mutka, 2011). Potřeba této integrace je ve strategických, koncepčních či kurikulárních dokumentech zdůrazňována dlouhodobě a je považována též za jednu z priorit vzdělávacích strategií vyspělých zemí (European Commission, 2013). Rozvoj digitálních kompetencí realizovaný na všech stupních škol, či v rámci dalšího vzdělávání by měl směřovat $\mathrm{k}$ cílové entitě tohoto edukačního působení, kterou je odpovídající úroveň digitální gramotnosti (Štípek a kol, 2015). Soudobé pojetí digitálních kompetencí vychází z jejich chápání jako schopností používat př́slušné vědomosti a dovednosti s odpovědností, autonomií, kritičností a tvưrčím zpo̊sobem (Ferrari, 2013). Základní rámec digitální gramotnosti, který nezahrnuje pouze technické dovednosti, ale též př́slušné vědomosti a postoje, obsahuje sedm oblastí dílčích kompetencí (Ala-Mutka, 2011):

- správa informací - identifikovat, lokalizovat, získávat, ukládat a organizovat informace,

- kolaborace - spojovat se s ostatními, participovat v on-line sítích a komunitách, konstruktivně komunikovat,

\footnotetext{
${ }^{1}$ WSIS - World Summit on the Information Society (http://www.itu.int/wsis/index.html), ACM Association for Computing Machinery (https://www.acm.org/), IFIP - International Federation for Information Processing (http://www.ifip.org)

${ }^{2} \mathrm{viz}$ http://www.vzdelavani2020.cz/images_obsah/dokumenty/strategie/digistrategie.pdf
} 
- $\quad$ komunikace a sdílení - komunikovat prostřednictvím on-line nástrojů se zohledněním bezpečnostních aspektů a ochrany osobních údajů,

- tvorba obsahu a znalostí - integrovat a přepracovat předchozí znalosti a obsah, budovat nové poznatky,

- $\quad$ etika a odpovědnost - chovat se eticky a odpovědně, být si vědom právních rámců,

- $\quad$ hodnocení a řešení problémů - identifikovat digitální potřeby, řešit problémy pomocí digitálních prostředků, vyhodnocovat získané informace,

- technické činnosti - používat technologie a média, provádět úlohy prostrednictvím digitálních nástrojů.

Nezastupitelnou roli při cíleném rozvoji digitálních kompetencí, resp. př́slušných kognitivních a operačních dovedností a postojů nezbytných kefektivnímu využití digitálních technologií mají základní školy, jakožto součást formálního systému vzdělávání. Zařazení informatických předmětů, jakožto standardní součásti kurikula základních škol, je rysem školských systémů vyspělých zemí. Jejich pojetí však není jednotné a rozdíly lze spatřovat jak v organizaci či formě příslušných edukačních aktivit, tak především v jejich rozsahu a obsahu (Štípek a kol, 2015). Podstatný vliv na tuto nejednotnost mají i rozličné didaktické přístupy, úroveň vybavenosti, ale také úroveň digitálních kompetencí samotných žáků. Nezanedbatelný vliv má i jistá „,nepružnost“ učitelů těchto předmětů, kteří velmi často akcentují spíše nácvik ovládání konkrétních softwarových nástrojů pro vyhledávání a zpracování především textových informací, místo cíleného rozvoje informatického myšlení žáků (Rambousek, Štípek \& Wildová, 2015).

K naznačenému pojetí rozvoje digitálních kompetencí žáků nevedla, alespoň v podmínkách českého školství, jednoduchá cesta. V průběhu času se totiž pojetí, obsah i zaměření výukových celků zaměřených na rozvoj kompetencí žáků v oblasti Informatiky měnili a to jednak $\mathrm{z}$ důvodu společenské poptávky, ale také v důsledku vývoje vlastních technologií.

\section{Koncepce výuky Informatiky v ČR,,včera“"}

Výuka informaticky zaměřených předmětů v rámci České republiky byla do kurikula základních škol závazně zakotvena zejména v rámci Vzdělávacího programu Základní škola ${ }^{3}$, který schválilo MŠMT dne 30. 4. 1996 s platností od 1. 9. 1996. Informatická témata byla $\mathrm{v}$ rámci tohoto vzdělávacího programu zastřešena povinným předmětem Praktické činnosti a volitelným předmětem Informatika.

V rámci předmětu Praktické činnosti, který byl povinně vyučován od 1. do 9. ročníku, byl zařazen mezi 6. až 9. ročníkem tematický celek Práce s počítačem. Výuka obsluhy počítače se tedy stala nedílnou součástí kurikula základních škol, byt' byla dovolena variantnost jejího časového zařazení do vzdělávání. Naproti tomu volitelný předmět Informatika mohl být do výuky zařazován od 7. ročníku do 9. ročníku. Úkolem volitelného předmětu bylo dotváření skladby povinných předmětů a ve své variantnosti byl jedním z prvků, kterým se vzdělávací program Základní škola odlišoval od jiných vzdělávacích

\footnotetext{
${ }^{3}$ viz http://www.msmt.cz/file/38757
} 
programů (Obecná škola ${ }^{4}$ a Národní škola ${ }^{5}$ ). V rámci takto komponované výuky Informatiky, byly vyučovány tyto doporučené tematické celky:

- Co rozumíme pojmem informace. Významné informační zdroje a informační instituce. Hodnota, cena informace a informační činnosti.

- Pokus o definici informace. Seznámení s důležitými informačními zdroje na klasických i magnetických nosičích. Důležité tuzemské i mezinárodní informační instituce. Návštěva některé dostupné informační instituce, počítačového pracoviště. Zjištění podmínek, za jakých se poskytují informace (jak rychle, za jakou cenu). Co se rozumí pojmem cena, hodnota informace, informační činnosti.

- Práce s textovými informacemi.

- Strukturovaná a nestrukturovaná organizace informací. Databázové a fulltextové systémy. Databáze dokumentografické (obsahující texty dokumentů) a faktografické (obsahující texty dokumentů) a faktografické (obsahující přímo fakta o skutečnosti).

- Vyhledávání informací.

- Vyhledávání informací pomocí klíčových slov, indexů. Formulace dotazu. Využití booleovské logiky při vyhledávání. Stanovení efektivnosti vyhledávání (kritérium přesnosti, úplnosti)

- Práce s tabulkovými procesy.

- Vytvoření jednoduché tabulky. Operace s čísly (sčítání, odčítání, násobení, dělení). Stanovení maximální, minimální, průměrné hodnoty. Grafické vyjádření hodnot tabulky.

- Přenos informací.

- Fax, e-mail, počítačová sít, internet, družicový přenos informací. Návštěva internetového pracoviště.

Pojetí obsahu předmětu tedy odpovídalo tehdejší úrovni a rozšiření výpočetní techniky v podmínkách České republiky, což je patrné zejména voblasti podpory přenosu a vyhledávání informací. Pozorný čtenář si také všimne, že byt' je v charakteristice předmětu explicitně uvedena potřeba seznámit žáka se základy algoritmizace a programování, $\mathrm{v}$ rámci žádného $\mathrm{z}$ doporučených témat již nebyla tato problematika podrobněji rozvíjena. Výuka tedy byla silně orientována na uživatelské dovednosti a znalosti, které mohl žák prakticky aplikovat, bez znalosti principů a vnitřního fungování využívaných zařízení a programů.

\section{Koncepce výuky Informatiky v ČR, ,dnes“}

Výše popsané pojetí se s postupujícím časem a rozvojem technologií ukázalo jako zastaralé a v rámci školské reformy z roku 2005, která zavedla v České republice zčásti decentralizovaný kurikulární systém, byla také provedena revize obsahu a pojetí výuky informatických předmětů. Provedená reforma v praxi znamenala, že školy získaly při tvorbě kurikulárních dokumentů částečnou autonomii, nicméně na obecné úrovni vymezovala obsah kurikula vláda, která stanovila tzv. Rámcové vzdělávací programy ${ }^{6}$

\footnotetext{
${ }^{4}$ viz http://www.msmt.cz/file/38752

${ }^{5}$ viz http://www.msmt.cz/uploads/soubory/zakladni/VP_Narodni_skola_v2007.pdf

${ }^{6} \mathrm{viz}$ http://www.msmt.cz/vzdelavani/skolstvi-v-cr/skolskareforma/ramcove-vzdelavaci-programy
} 
(dále jen RVP). Na podobě a tvorbě konkrétní podoby kurikula jednotlivých vzdělávacích oblastí, tedy i oblasti zaměřené na informatická témata, se podíleli sami učitelé jednotlivých škol. Ti vytvářeli podle RVP Školní vzdělávací programy (dále jen ŠVP) tak, aby splnily závazné požadavky stanovené $\mathrm{v}$ RVP a přizpůsobily plány výuky jednotlivých předmětů co nejvíce potřebám svých žáků a školy.

Základní myšlenkou celého pojetí bylo to, aby tvorba ŠVP a učebních plánů všech vyučovacích hodin cíleně spěla k rozvíjení tzv. klíčových kompetencí žáků. Rozvoj těchto kompetencí bylo promítnuto do devíti vzdělávacích oblastí. Jednou z klíčových oblastí vzdělávání se stala také oblast Informační a komunikační technologie. Zatímco jiné vzdělávací oblasti zabírají v kurikulárním dokumentu RVP ZV až téměř deset stran, Informační a komunikační technologie se s charakteristikou, cíli, očekávanými výstupy a učivem vešly s rezervou na strany tři. V několika odstavcích o charakteristice vzdělávací oblasti (MŠMT, 2017, str. 38) je např́klad uvedeno:

- Žáci musí mít možnost dosáhnout základní úrovně informační gramotnosti,

- žáci získají elementární dovednosti při práci s výpočetní technikou, orientují se ve světě informací a dokáží s nimi tvořivě pracovat,

- získané dovednosti při práci s výpočetní technikou jsou podmínkou k efektivnímu profesnímu rozvoji i k jiným zájmovým činnostem,

- umění rychlého vyhledávání a zpracování informací pomocí ICT prostředků umožňuje odlehčit jejich pamět',

- dovednosti získané $\mathrm{v}$ této vzdělávací oblasti je možno aplikovat napríč všemi ostatními obory, a ICT se tak stává součástí všech vzdělávacích oblastí základního vzdělávání.

Pro 1. stupeň ZŠ je kurikulum tematické oblasti Informační a komunikační technologie rozděleno do tř́ částí: Základy práce s počitačem, Vyhledávání informací a komunikace a Zpracování a využití informací. Každá část specifikuje očekávané výstupy, které se zaměřují na to, co žák dovede na konci daného období. Pro lepší představu jako pomůcka při tvorbě ŠVP je zde také uvedeno učivo, které se k daným výstupům váže (MŠMT, 2017, str. 39):

- základní pojmy informační činnosti - informace, informační zdroje, informační instituce,

- struktura, funkce a popis počítače a př́idavných zařízení,

- operační systémy a jejich základní funkce,

- seznámení s formáty souborů (doc, gif),

- multimediální využití počítače,

- jednoduchá údržba počítače, postupy při běžných problémech shardware a software, zásady bezpečnosti práce a prevence zdravotních rizik spojených s dlouhodobým využíváním výpočetní techniky,

- společenský tok informací (vznik, přenos, transformace, zpracování, distribuce informací),

- základní způsoby komunikace (e-mail, chat, telefonování),

- metody a nástroje vyhledávání informací,

- formulace požadavku při vyhledávání na internetu, vyhledávací atributy,

- základní funkce textového a grafického editoru. 
Obsah vzdělávací oblasti pro 2 . stupeň je v RVP ZV shrnut do dvou tematických částí Vyhledávání informací a komunikace a Zpracování a využití informací. Tyto tematické části jsou koncipovány jako nadstavba již probíraného učiva $\mathrm{v}$ rámci 1 . stupně a rozšiřuje je o nové možnosti aplikace. Bohužel nedochází ale $\mathrm{k}$ tomu, aby byl rozšířen obsah vzdělávání i o další oblasti a proto jsou pouze propracována témata stávající. I tyto tematické části se dělí na Očekávané výstupy a Učivo (MŠMT, 2017, str. 40):

- vývojové trendy informačních technologií,

- hodnota a relevance informací a informačních zdrojů, metody a nástroje jejich ověřování,

- internet,

- počítačová grafika, rastrové a vektorové programy,

- tabulkový editor, vytváření tabulek, porovnávání dat, jednoduché vzorce,

- prezentace informací (webové stránky, prezentační programy, multimédia),

- ochrana práv k duševnímu vlastnictví, copyright, informační etika.

Vzhledem $\mathrm{k}$ tomu, že učitelé mají často velké potíže sestavit podle výše zmíněných bodů školní vzdělávací program, stává se, že od sebe školy navzájem „opisuji“ (Strnad, 2015). Aby byl tento jen alespoň částečně eliminován, vypracovala skupina odborníků a samotných učitelů základních škol Standardy pro základní vzdělávání - Informační a komunikační technologie ${ }^{7}$. Tyto navržené standardy slouží učitelům nejen při prípravě ŠVP, ale především při evaluaci dosažení očekávaných výstupů podle RVP ZV. Například výše zmíněné části v 1 . ročníku - Zpracováni a využití informací, která je shrnuta do jedné věty, co se týče očekávaného výstupu a taktéž, co se týče učiva - je ve standardech věnovaná celá strana se šesti indikátory a podrobně popsanou ilustrativní úlohou. Je škoda, že tento dokument vznikl až v roce 2013, tzn. šest let po začátku platnosti RVP a zatím existuje pouze $\mathrm{v}$ pracovní verzi (dosud nebyl oficiálně schválen MS̆MT).

\section{Koncepce výuky Informatiky v ČR ,zítra““}

Když byla v roce 2001 schválena tzv. Bílá kniha, jakožto oficiální státní dokument vytyčující cíle rozvoje vzdělávání v České republice, byla tímto nastartována i systémová změna vzdělávací politiky, která se v konečném důsledku promítla do Národního vzdělávacího programu, jehož součástí byl i vznik Rámcových vzdělávacích programů. Přestože se nedá ríct, že by $\mathrm{k}$ dílčím pokrokům $\mathrm{v}$ určitých oblastech školního vzdělávání nedocházelo (Strnad, 2015), chybělo systematické plnění dlouhodobého plánu a „vytrácelo se védomi vazeb a souvislostí mezi jednotlivými součástmi vzdělávacího systému“" (MŠMT, 2014a). V souvislosti s tím ukázalo mezinárodní šetření PISA (z roku 2012), že výsledek českých patnáctiletých žáků $\mathrm{v}$ matematice je průměrný a v porovnání $\mathrm{s}$ výsledky $\mathrm{z}$ roku 2003 došlo k výraznému zhoršení (Palečková, Tomášek \& kol., 2013). Aby se zabránilo podobnému nekonzistentnímu a stagnujícímu vývoji vzdělávací politiky v následujících letech, sestavilo ministerstvo dokument, který by měl nastavit směr dalš́ího rozvoje českého vzdělávání v letech 2015 - 2020. Strategie vzdělávací politiky České republiky do

\footnotetext{
${ }^{7}$ Standardy pro základní vzdělávání: Informačni a komunikačni technologie. Pracovní verze z 30. 4. 2013. Dostupné z URL:

http://clanky.rvp.cz/wpcontent/upload/prilohy/17383/informacni_a_komunikacni technologie.pdf
} 
roku $2020^{8}$ byla schválen v červenci 2014 , a tím tak definitivně pozbývá platnost Národní program rozvoje vzdělávací soustavy (Bílé knihy) z roku 2001 (MŠMT, 2014a, str. 3).

Souběžně s tvorbou této strategie 20 . března 2013 schválila vláda České republiky koncepci Digitální Česko v. 2.0, Cesta k digitální ekonomice. Koncepce konkrétně uvádí: „Informačni technologie by měly prostupovat celým procesem výuky na základních školách, nikoli jen v predmětech typu ,Práce s počítačem: Plné zapojení modernich technologii do výuky všech předmětů vnímá stát jako nezbytné v rámci posunu vzdèlávacího systému od prostého memorováni faktů $k$ důrazu na čtenářskou gramotnost, komunikačni dovednosti a logické myšleni"“. Součástí usnesení vlády k této koncepci je soubor opatření, z nichž se opatření č. 16 týká problematiky vzdělávání a ukládá MPSV (Ministerstvo práce a sociálních věcí ČR) ve spolupráci s MŠMT (Ministerstvo školství, mládeže a tělovýchovy ČR) vypracovat strategii pro zvýšení digitální gramotnosti a rozvoj elektronických dovedností občanů. Strategie digitálního vzdělávání naplňuje toto usnesení vlády pro oblast počátečního vzdělávání. Strategie pro zvýšení digitální gramotnosti a rozvoj elektronických dovedností občanů vznikala paralelně se Strategií digitálního vzdělávání a měla na ni bezprostředně navazovat. Přímou iniciací vzniku dokumentu Strategie digitálního vzdělávání pak bylo vládou přijaté Usnesení č. 790 ze dne 16. října 2013 ke strategickému záměru Digitální vzdělávání - Touch your future.

Hlavní myšlenkou schválené vzdělávací politiky České republiky je celoživotní učení - stejně jako hlavní cíl strategického rámce ET 2020 (Rada EU, 2011) členských států Evropské unie. Hlavním cílem je tedy poskytnout kvalitnější a efektivnější vzdělávání, a přispět tak $\mathrm{k}$ naplnění cílů strategie Evropa 2020, tedy $\mathrm{k}$ podpoře zvyšování konkurenceschopnosti a růstu EU prostřednictvím lépe kvalifikované pracovní síly a větší zaměstnanosti. Navrhuje sérii klíčových transformačních opatření na úrovni EU a na vnitrostátní úrovni, která se týkají zejména:

- pomoci vzdělávacím institucím, učitelům a žákům získat digitální dovednosti a osvojit si strategie učení,

- podpory rozvoje a dostupnosti otevřených vzdělávacích zdrojů,

- propojení tříd a zavádění digitálních zařízení a obsahu,

- mobilizace všech zúčastněných stran (učitelů, studentů, rodin, hospodářských a sociálních partnerů), jejímž cílem je změnit úlohu digitálních technologií ve vzdělávacích institucích.

Hlavní vizí Strategie digitálního vzdělávání do roku 2020 je vytvoření vzdělávacího systému, který bude schopen zajišt'ovat výbavu každého jedince bez rozdílu takovými kompetencemi, které mu umožní se uplatnit v informační společnosti a využívat nabídky otevřeného vzdělávání v průběhu celého života. Postavena je tedy na čtyřech základních pilírích (MŠMT, 2014b, str. 11-12):

- Otevřené vzdělávání: vychází z principu celoživotního učení a směřuje k vybudování otevřeného prostředí, které umožňuje každému jedinci bez rozdílu a bez překážek vzdělávat se po celý život. Takové vzdělávání tím, že využívá dostupné digitální technologie a podporuje jedince v jejich využívání, bude stále více chápáno jako aktivita bez vazby na konkrétní místo a konkrétní čas. Budou se na něm podílet poskytovatelé $\mathrm{z}$ veřejného, soukromého i neziskového sektoru -

\footnotetext{
${ }^{8}$ viz http://www.vzdelavani2020.cz/images_obsah/dokumenty/strategie-2020_web.pdf
} 
organizace i jedinci, kteří budou nabízet obsah, vzdělávací příležitosti a výuku studujícím v každém věku.

- Digitální gramotnost: vychází z vymezení digitálních kompetencí v publikaci Evropské komise DIGCOMP: Rámec rozvoje digitálních kompetencí a porozumění digitálním kompetencím v Evropě (DIGCOMP: A Framework for Developing and Understanding Digital Competence in Europe), jež navazuje na Doporučení Evropského parlamentu a Rady ze dne 18. prosince 2006 o klíčových schopnostech pro celoživotní učení. V tomto rámci jsou digitální kompetence pojaty jako soubor vědomostí, dovedností, schopností, postojů a hodnot, které potřebujeme k sebejistému, kritickému a tvořivému využívání digitálních technologií při práci, v zaměstnání, při učení, ve volném čase i při zapojení do společenského života.

- Informatické myšlení (computational thinking): je fenomén, jehož význam se do popředí zájmu dostává až v posledních letech. Jde o relativně nový pojem29, který odráží potřebu porozumění světu kolem nás z nové perspektivy. Touto perspektivou jsou informace a způsoby, jakými fungují digitální technologie. Jde o způsob uvažování, který používá informatické metody řešení problémů, a to včetně problémů komplexních či nejasně zadaných. Rozvíjí schopnost analyzovat a syntetizovat, zevšeobecňovat, hledat vhodné strategie řešení problémů a ověřovat je v praxi. Vede $\mathrm{k}$ přesnému vyjadřování myšlenek a postupů a jejich zaznamenání ve formálních zápisech, které slouží jako všeobecný prostředek komunikace. Pracuje se základními univerzálními pojmy, které přesahují současné technologie: algoritmus, struktury, reprezentace informací, efektivita, modelování, informační systémy, principy fungování digitálních technologií.

- Digitální technologie ve vzdělávání: reaguje na skutečnost, že digitální technologie čím dál více ovlivňují prostředí, ve kterém žijeme, a bezprostředně i naše životy, je v dnešní době již nezpochybnitelná. Stejně jako je tomu v ostatních oborech lidské činnosti, lze pozorovat technologické trendy, které ovlivňují pedagogiku, školství a vzdělávání. Tyto trendy procházejí při pronikání na trh a šírení ve společnosti určitými fázemi, které lze pomocí vhodných nástrojů a postupů sledovat a $\mathrm{s}$ jistou mírou určitosti i předpovídat jejich další šíření. Problematice významných technologických trendů se věnují mnohé předpovědi budoucího vývoje. Mezi nejprestižnější a široce uznávané patří Horizon Report. Tento každoročně publikovaný dokument předpovídá ve třech časových horizontech dva nejdůležitější klíčové trendy urychlující přijetí digitálních technologií ve školách.

Jak je z uvedeného přehledu opatření patrné, Strategie digitálního vzdělávání do roku 2020 naznačuje cestu, na konci které může být systémová změna, odstraňující současnou absenci či nekonzistentnost informatického obsahu kurikula. Přričiny problému absence informatického obsahu ve školním kurikulu na základních školách a nedostatku podpory učitele pro výuku informatických témat, je možné spatřovat především v přetrvávající orientaci školního vzdělávání na konzumaci digitálních technologií, na uživatelský přístup. Aplikací této zastaralé orientace, při které jsou digitální technologie pouze používány, a tím není cíleně vzdělávána skupina lidí, která by měla technologie vyvíjet a do hloubky jim rozumět, být schopná výzkumu a inovací v této oblasti.

Příčiny jsou dány historickým nasměrováním výuky vzdělávací oblasti ICT, opírající se o návrh modelu ICT rozvoje $\mathrm{v}$ kurikulu od UNESCO z roku 2002, které 
upřednostňovaly uživatelský př́stup a odmítaly informatické vzdělání pro běžnou populaci. Na současné úrovni poznání je ale stále více jasné, že informatika, stejně jako další prírodní vědy, má velký př́nos pro pochopení současného světa a mnoho aplikovatelných poznatků. Informatická témata, i ta složitější jako je např́ílad algoritmizace, lze učit (úměrně schopnostem žáka) od útlého věku, podobně jako ostatní vědní obory. A stejně jako ostatní vědy má informatika své pojmy, principy a zákonitosti, kterým je třeba porozumět, což je důležitější než jen takové nástroje používat. V souladu s tímto také současný návrh UNESCO (EDUsumMIT, 201797) upozorňuje, že zaměření jen na digitální gramotnost je minulostí. Současný udržovaný stav je způsoben také stávajícími, notně zastaralými RVP, které nebyly po téměř 10 let inovovány a které do jisté míry svazují učitele a směřují jej $\mathrm{k}$, ve světě už dávno překonanému modelu, výuky v této vzdělávací oblasti.

Jak tedy vypadá konkrétní vzdělávací obsah informatických předmětů na 1.2. stupni českých základních škol? Která informatická témata jsou ve skutečnosti vyučována? Objevují se ve výuce i témata, která nejsou v rámci RVP zakotvena či př́liš akcentována? Na tyto otázky se pokusíme odpovědět v rámci další části předložené stati, ve které budou analyzovány Školní vzdělávací plány (ŠVP) základních škol.

\section{Analýza obsahu výuky Informatiky v ČR}

Praktická realizace výuky Informatiky, respektive informaticky zaměřených předmětů, je zakotvena v rámci kurikulárních dokumentů jednotlivých školských zařízení, které jsou vytváŕeny v souladu se školskou reformou z roku 2005. Ta zavedla systém vzdělávacích programů a dvoustupňovou tvorbu kurikula, která se týká primárního i sekundárního vzdělávání (MŠMT, 2017). Jak již bylo uvedeno, tento systém tvoří především Rámcové vzdělávací programy (RVP) a Školní vzdělávací programy (ŠVP), kdy Ministerstvo školství, mládeže a tělovýchovy ČR (MŠMT ČR) vydává závazné Rámcové vzdělávací programy pro jednotlivé obory vzdělání, podle kterých vytváŕí školy vlastní Školní vzdělávací programy. Cílem tvorby tohoto opatření bylo především umožnit pružnější profilaci absolventů podle podmínek konkrétní školy, potřeb regionálního trhu práce, vývoje oboru, schopností a zájmů žáků a zároveň zajistit, že se všem žákům dostane srovnatelného vzdělání odpovídajícího potřebám moderního trhu práce i občanského života (Walterová, 2004). Kurikulární reforma tak dala možnost školám vytvářet vlastní vzdělávací programy a být nejen realizátorem vzdělávání, ale podílet se i na jeho projektování (Tupý, 2014). Školní vzdělávací programy tak vytvářejí školy podle RVP pro danou oblast vzdělání, kterou chtějí realizovat. Rámcový program rozpracovávají ve svém ŠVP s ohledem na žáka, vzdělávací podmínky v dané škole, potřeby regionálního trhu práce a podle záměrů rozvoje školy. ŠVP nejsou institucionálně schvalovány, za jejich zpracování je odpovědný ředitel školy. Musí být zveřejněny na veřejně př́stupném místě ve škole.

Školám se tak dostalo možnosti, přizpůsobovat obsah vzdělávání specifickým potřebám svých žáků, specifikům daného regionu, ale i specifikům vlastní školy. V rámci RVP bylo vymezeno devět vzdělávacích oblastí, mezi něž patři i vzdělávací oblast Informační a komunikační technologie. V rámci tvorby ŠVP jednotlivých škol tedy vznikl prostor pro realizaci výuky informatických témat, která nemusí být pevně zakotvena $\mathrm{v}$ rámci RVP pro oblast Informační a komunikační technologie, nebot' celý systém

\footnotetext{
${ }^{9}$ viz http://unesco.unibit.bg/en/EDUsummIT17
} 
umožňuje relativní volnost volby obsahu či formy naplňování klíčových kompetencí žáků. Tato relativní volnost je také dána značnou vágností vymezení charakteristiky a obsahu vzdělávací oblasti Informační a vzdělávací technologie, která spiše specifikuje očekávané výstupy, které se zaměřují na to, co žák dovede na konci daného období, než aby vymezovala konkrétní učivo.

Pokud tedy chceme zjistit, co se dnes na českých základních školách $\mathrm{v}$ rámci vzdělávací oblasti Informační a komunikační technologie skutečně učí, nezbývá nám, než podrobně analyzovat ŠVP jednotlivých škol pro tuto oblast. Ještě před provedeným vlastní analýzy bylo možné předpokládat, že jednotlivá konkrétní informatická témata bude zřejmě možné rozdělit na „,tradični'“ téma, tedy ta, která jsou pevně zakotvena v rámci RVP pro oblast Informační a komunikační technologie a „netradiční“ témata, tedy ta, u nichž se zařazení př̌edpokládá až v rámci implementace Strategie digitálního vzdělávání do roku 2020.

Dále prezentovaná analýza ŠVP pro vzdělávací oblast Informační a komunikační technologie, byla provedena na celkem 17 základních školách, které se nacházejí na území tř́ krajů České republiky (Olomoucký, Moravskoslezský, Zlínský). Struktura škol byla volena tak, aby zaručovala co nejvyšší vypovídající hodnotu zjištěných výsledků, kdy byly zastoupeny jak malé školy do 200 žáků, tak školy se střední velikostí od 200 do 500 žáků a také školy s velkou velikostí nad 500 žáků. Zřetel byl také brán na poměrné zastoupení škol venkovských a městských, byt' jsme se nedomnívali, že vybavení venkovských škol může vykazovat vyšší míru nedokonalosti a nekompletnosti, než je tomu u škol městských. Nicméně je nutné prripustit i fakt, že dostatek vhodného vybavení pro zajištění výuky Informačních a komunikačních technologií je jednou z podmínek jeho smysluplného implementování do výuky ve školách, nebot' samotné vlastnictví těchto nástrojů ještě neznamená, že jsou skutečně využivány (Klement, Dostál \& Bártek, 2017). Další podmínkou pro zařazení dané školy do analýzy jejího ŠVP ve vzdělávací oblasti Informační a komunikační technologie byla skutečnost, zda škola realizuje výuku pro 1. i 2. stupeň vzdělávání, nebot' by jinak byly pořízené výsledky neporovnatelné. Abychom tedy mohli popsat skutečný obsah výuky informatických předmětů vyučovaných na základních školách ve vzdělávací oblasti Informační a komunikační technologie, provedli jsme analýzu ŠVP zkoumaných sedmnácti škol. Analýza byla provedena metodou řízeného strukturovaného pozorování četností výskytu konkrétních tematických celků a to plně s jejich deklarovaným obsahem na úrovni ŠVP. s ohledem na různorodost propracování popisu výukových obsahů a učiva na úrovni jednotlivých ŠVP, byly z těchto obsahů vybrány nejdůležitější společné celky a činnosti.

$\mathrm{V}$ níže uvedené tabulce je tedy zachycen reálně realizovaný vzdělávací obsah zakotvený v rámci ŠVP sedmnácti zkoumaných škol. Je samožrejmě možné namítnout, že deklarovaný obsah ŠVP školy nemusí nutně korespondovat se skutečným obsahem realizované výuky, ale detailní propracování jednotlivých ŠVP až na úroveň konkrétního učiva (v prípadě několika ŠVP byl obsah propracován až na úroveň jednotlivých vyučovacích hodin) nás vedl $\mathrm{k}$ závěru, že míra odchylky bude spíše symbolická a neměla by realizovanou analýzu a její výsledky př́liš ovlivňovat. Dodržování náplně stanovených RVP a ŠVP je také předmětem detailních kontrol ze strany České školní inspekce, která se také zajímá o soulad konkrétní náplně vyučovacího předmětu a jeho skutečnou realizaci, formou hospitačních návštěv v hodinách. Výsledek této analýzy prezentuje graf číslo 1 . 


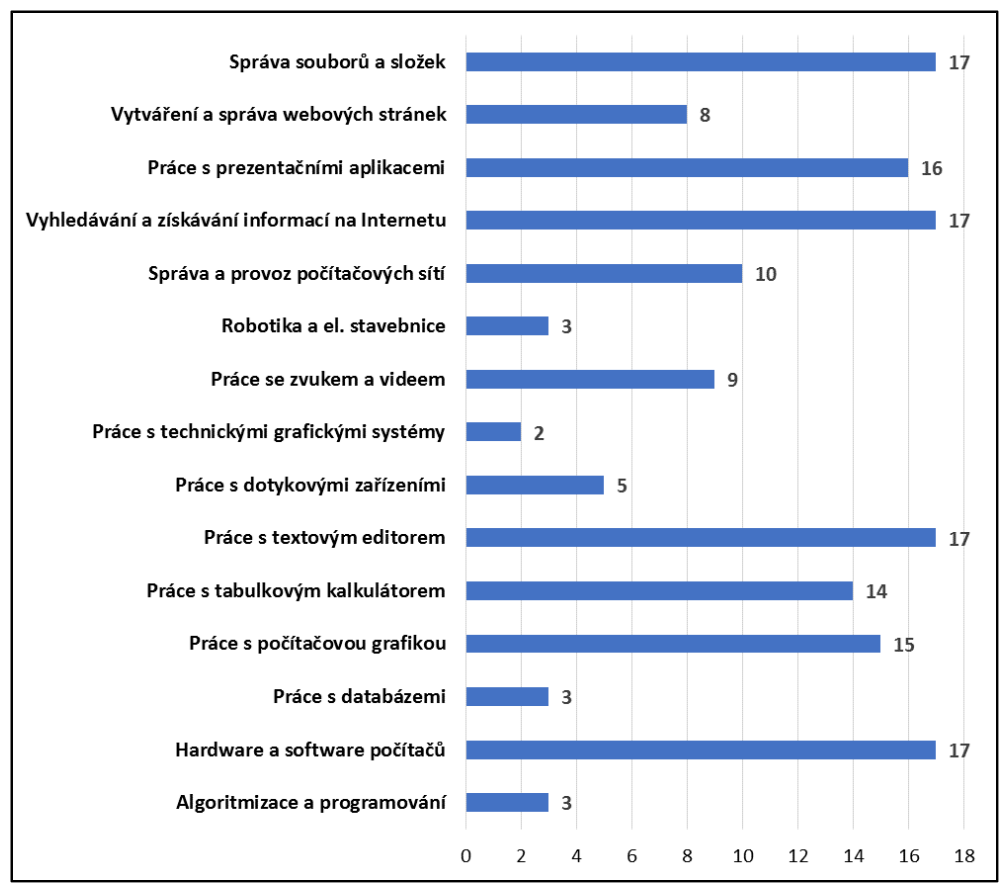

Graf č. 1: Četnosti výskytů tematických celků

Z uvedeného přehledu jasně vyplývá, že nejvyšší míru zastoupení ve výuce na základních školách mají tematické celky „Správa souborů a složek“, „Vyhledávání a získávání informací na Internetu“, „Práce s textovým editorem“ a „Hardware a software počítačü“. Tyto tematické celky byly obsaženy ve všech sedmnácti ŠVP zkoumaných škol. $\mathrm{K}$ těmto nejvíce zastoupeným tematickým celkům je možné ještě připočíst tematické celky „Práce s prezentačními aplikacemi“, „Práce s tabulkovým kalkulátorem“ a „práce s počítačovou grafikou“, které byly obsaženy ve velké většině ŠVP škol. Tento výsledek je logický, nebot' tyto tematické celky jsou pevně zakotveny rozpracovány v rámci RVP pro vzdělávací oblast Informační a komunikační technologie.

Další relativně četně zastoupené tematické celky jsou „Vytváření a správa webových stránek“, „Správa a provoz počítačových sítí“ a „Práce se zvukem a videem“. Tyto tematické celky byly zastoupeny v ŠVP více než 50 \% zkoumaných škol, což je zřejmě důsledkem jejich volitelnosti. Byt' tedy nejsou $\mathrm{v}$ rámci RVP pro vzdělávací oblast Informační a komunikační technologie explicitně zakotveny, některé z „tradičních“ tematických celků se jich dotýkají či jim poskytují potřebný základ. Svou roli zde zřejmě hraje i vysoká oblíbenost témat řešených v rámci těchto tematických celků, nebot' vytváŕení videí a webových prezentací (napr. fenomén tzv. youtuberů), je dnes mezi žáky vyhledávaná a oceňovaná dovednost, kterou zřejmě učitelé ve své výuce reflektují.

Překvapivé je, že „netradiční“ tematické celky „Robotika a el. stavebnice“, „Práce s technickými grafickými systémy“, „Práce s dotykovými zařízeními“, „Práce 
s databázemi““ a především „Algoritmizace a programování“ nejsou zastoupeny ojediněle a mají vyšší četnost výskytu, než by se dalo očekávat. Tyto tematické celky nejsou v rámci RVP pro oblast Informační a komunikační technologie prakticky zmíněny, a jejich výskyt na školách je výlučně spjat s vůlí vyučujících či vedení školy. Jedná se také o některé tematické celky, které by měly být rozvíjeny v souladu s implementací Strategie digitálního vzdělávání do roku 2020, ale je zřejmé, že učitelé již nyní cítí potřebu jejich zařazování do výuky, což je zjištění velmi pozitivní.

Samotný výskyt daného celku, byt' je překvapivý, ale ještě nemusí znamenat jeho oblíbenost u žáků či jeho potřebnost a prrínosnost $\mathrm{z}$ pohledu učitelů. Mohou také existovat diferencované rozdíly v úrovni znalostí a dovedností žáků v jednotlivých celcích, které mohou být způsobeny i odlišným príistupem ke vzdělávacímu obsahu a problematice samé. Abychom mohli tyto závislosti a vnitřní vztahy pochopit a popsat, bylo nutné realizovat výzkumné šetření zaměřené na problematiku akceptace výukového obsahu informatických předmětů, vyučovaných na základních školách v České republice, jehož metodologie, cíle a výsledky jsou uvedeny v navazující části stati.

\section{Zaměření, cíle a metodologie realizovaného výzkumného šetření}

$\mathrm{V}$ předchozím textu byly popsány některé $\mathrm{z}$ rozvojových trendů souvisejících $\mathrm{s}$ rozvojem obsahu a forem výuky informatických předmětů $\mathrm{v}$ rámci vzdělávací soustavy České republiky, ale také v zahraničí. Pokusili jsme se také naznačit některá úskalí či výzvy, které tento rozvoj determinují. Určit, do jaké míry jsou tyto trendy, úskalí či výzvy signifikantní není možné, aniž bychom tuto problematiku bliže nezkoumali pomocí metod pedagogického výzkumu. Toto zkoumání, zaměřené na zjištění aktuálního stavu akceptace výukového obsahu informatických předmětů, vyučovaných na základních školách v České republice, bylo realizováno na základě výzkumného šetření, které probíhalo v rámci 35-ti mateřských, základních či středních škol a to v průběhu roku 2017.

Tato naše snaha navazovala na některá vybraná výzkumná šetření, která mapovala skutečnou situaci výuky informatických předmětů na českých školách. Z tuzemské provience můžeme uvést např́klad výzkum Informačně technologické kompetence dětí a jejich rozvoj na základnich školách, realizovaný v rámci projektu Grantové agentury ČR (tzv. GAČR) v letech 2012 - 2013 pod vedením V. Rambouska. Uvedený projekt zkoumal postoje učitelů a žáků $\mathrm{k}$ jednotlivým tématům výuky ICT a pokusil se tak zmapovat stav a pojetí rozvoje IT kompetencí učitelů a žáků (Rambousek, 2013). Také v zahraničí je tato problematika zkoumána a řešena. Např́ílad v roce 2012 zveřejnila The Royal Society zprávu Shutdown or restart?: The way forward for computing in UK schools, kterou lze považovat za jeden $\mathrm{z}$ výchozích dokumentů pro vymezení nového anglického kurikula informatických předmětů. Na základě tohoto dokumentu se rozhodli britští specialisté provést vlastní projekt - Computing in Schools (probíhající od srpna roku 2010 do roku 2012 na vybraných školách v Anglii), který měl poskytnout dostatečně průkazný a nestranný pohled na současnou situaci ICT kurikula v Anglii a vyvodit $\mathrm{z}$ něho návrhy na př́ípadné změny (The Royal Society, 2012). Také v Americe se otázce výuky informatických témat na základních školách věnují už několik let. Především organizace CSTA (Computer Science Teachers Association) a její nadřazená asociace ACM (Association for Computing Machinery) se v nedávné minulosti velice aktivně angažovaly v př́ípravě standardů pro výuku informatických předmětů (přesněji Computing Science) pro žáky K-12, tedy pro žáky od prvního do dvanáctého ročníku základních škol (CSTA, 2011). 
Dále prezentovaný výzkum byl tedy primárně zaměřen na problematiku akceptace výukového obsahu informatických předmètů, vyučovaných na základních školách v České republice a cílovou skupinu tak tvořili žáci 9. tříd základních škol. Předmětem výzkumné činnosti se tak stala problematika digitálních kompetencí a jejich rozvoje v kontextu soudobého pojetí konceptu digitální gramotnosti s přesahem do možnosti modernizace vzdělávacího obsahu akceptujícího potřeby rozvoje digitálního myšlení žáků. Předmět výzkumu byl konkretizován do dvou relativně samostatných výzkumných oblastí:

- Jednou z výzkumných oblastí bylo zjištění subjektivní úrovně znalostí $\mathrm{v}$ informaticky zaměřených tématech či výukových celcích, v nichž jsou na základních školách cíleně rozvíjeny př́islušné digitální kompetence žáků.

Důležitým faktorem pro vyhodnocení celkové situace v oblasti akceptace výukového obsahu informatických předmětů, vyučovaných na základních školách v České republice, je také nezávislost získaných výsledků na některých signifikantních znacích skupin respondentů, jako je gender respondentů. I když je využití genderu u výzkumů někdy právem kritizováno, domníváme se, že existují podstatné důvody, proč toto porovnání $\mathrm{v}$ tomto specifickém prípadě využít. Tuto důležitou vlastnost skupiny žáků 9. trí́d základních škol, nebylo tedy možné pominout, nebot' explanace stavu, která zcela závisí na pohlaví, není možné označit za plně validní. $Z$ těchto důvodů bylo záměrem podrobit získané výsledky i analýzám, které by se zabývaly ověřením relativní nezávislosti na některých důležitých vlastnostech výzkumného vzorku. Byla tedy formulována výzkumná hypotéza:

- Žáci 9. tř́íd základních škol - chlapci, deklarují vyšší úroveň znalostí v tematických celcích informatiky než žáci 9. tříd základních škol - dívky.

Jako základní prostředek pro získání dat, potřebných pro realizaci výzkumného šetření, byl použit dotazník. Ve struktuře klasifikace výzkumných metod patří dotazník mezi neprímé - vyšetřovací metody. Dotazník lze charakterizovat jako „měrný prostředek, pomocí kterého se zkoumaji míněni lidí o jednotlivých jevech" (Chráska \& Kočvarová, 2015). Zkoumané jevy se mohou z hlediska jednotlivce (respondenta) vztahovat bud' $\mathrm{k}$ vnějším jevům, nebo $\mathrm{k}$ vnitřním dějům. Pro potřeby výzkumného šetření byl tedy, na základě výše vymezených výzkumných otázek a hypotéz, zkonstruován strukturovaný dotazník (Gavora, 2010), pomocí kterého bylo možné zjišstovat názory žákủ 9. tř̌́d základních škol na zkoumané jevy. Dotazník obsahoval jak uzavřené otázky s nabízenou odpovědí, tak polouzavřené otázky se škálou odpovědí (využita byla čtyřstupňová škála), ale i otevřené otázky, pomocí kterých mohli respondenti zaznamenat variantní stav sledovaných jevů. Aby byla zajištěna srozumitelnost jednotlivých dotazníkových otázek, byl dotazník opatřen vysvětlujícím textem, který vymezoval jednotlivé použité termíny. Výzkumný dotazník obsahoval 9 dotazníkových položek, které byly zaměřeny na zkoumané jevy, a zahrnoval také další informační aparát, pomocí kterého byly zjištovány některé signifikantní znaky respondentů, jako pohlaví, věk žáků a lokace navštěvované školy. Vytvořený výzkumný dotazník byl v období od dubna až června roku 2017, distribuován mezi žáky 9. tř́́d celkem 35 základních škol, přičemž se tyto školy nacházely na území tří krajů České republiky (Olomoucký, Moravskoslezský, Zlínský). Celkově dotazník vyplnilo 342 respondentů, žáků 9. trííd základních škol. Podrobný popis výzkumného vzorku je uveden v tabulce číslo 1 . 


\begin{tabular}{|c|c|c|c|c|}
\hline Znak & Skupina & Četnost & Četnost v \% & Celková četnost \\
\hline \multirow{2}{*}{ Pohlaví } & chlapci & 144 & 42,1 & \multirow{2}{*}{342} \\
\hline & dívky & 198 & 57,9 & \\
\hline \multirow{2}{*}{ Věk } & 14 let & 130 & 38,0 & \multirow{2}{*}{342} \\
\hline & 15 let & 212 & 62,0 & \\
\hline \multirow{2}{*}{ Lokace školy } & ve městě & 195 & 57,0 & \multirow{2}{*}{342} \\
\hline & na vesnici & 147 & 43,0 & \\
\hline
\end{tabular}

Tab. č. 1: Struktura výzkumného vzorku

Pro zjištění mocnosti jednotlivých skupin respondentů, kteří odpovídali stejným způsobem, bylo použito základních popisných statistik a jejich vizualizace pomocí grafů. Dále byly tato výsledky podrobeny analýze, na nichž byla sledována míra důležitosti odpovědí pro jednotlivé skupiny respondentů, rozdělených dle signifikantních znaků (pohlaví). Na toto ověření jsme použili parametrický Studentův t-test pro nezávislé skupiny, který porovnává průměry jedné proměnné ve dvou skupinách (Chráska \& Kočvarová, 2015). Pro všechny tyto výpočty a vizualizace byl použit

V dalším textu jsou uvedeny některé dílčí výstupy realizovaného výzkumného šetření, které bylo primárně zaměřeno na problematiku akceptace výukového obsahu informatických předmětů, vyučovaných na základních školách v České republice, a jehož cílovou skupinou byli žáci 9. tř́id. Součástí výzkumu byla i oblast akceptace prŕípadné změny vzdělávacího obsahu směrem k podstatnému rozšíření výuky algoritmizace a programování.

\section{Aktuální úroveň znalostí v informatických tématech žáků 9. tříd základních škol}

První výzkumnou oblastí bylo zjištění subjektivní úrovně znalostí v informaticky zaměřených tématech či výukových celcích, v nichž jsou na základních školách cíleně rozvíjeny př́islušné digitální kompetence žáků. Slovo subjektivní je uvedeno záměrně, nebot' míru znalostí posuzovali samotní žáci, což může vést ke zkreslení skutečné úrovně znalostí, nebot' je možné že žáci záměrně či nezáměrně snižovali či zvyšovali deklarovanou úroveň svých znalostí. Nicméně musíme uvést, že zjištění aktuální a skutečné úrovně znalostí nebylo ani naším záměrem, jinak bychom museli deklarovanou úroveň konfrontovat s hodnocením učitelů či klasifikací, a chtěli jsme spíše zjistit, ve kterých tematických celcích se žáci cítí více, a ve kterých tématech potom méně zdatní.

Dále jsme předpokládali, že žáci budou zřejmě deklarovat vyšší úroveň znalostí $\mathrm{v}$,tradičních“ tématech, tedy $\mathrm{v}$ těch tématech, která jsou pevně zakotvena v rámci RVP pro oblast Informační a komunikační technologie. Naopak jsme předpokládali, že nižší úroveň znalostí bude deklarována u „netradičních“ témat, tedy u těch, jejichž zařazení předpokládá až v rámci implementace Strategie digitálního vzdělávání do roku 2020. Sumarizace odpovědí žáků 9 . tříd je uvedena v tabulce číslo 2 , na jejímž základě bylo také možné přistoupit k ověřování stanoveného výzkumného předpokladu.

\begin{tabular}{|c|c|c|c|c|c|}
\hline \multirow{2}{*}{ Tematický celek } & \multicolumn{5}{|c|}{ Deklarovaná úroveň znalostí } \\
\cline { 2 - 6 } & $\begin{array}{c}\text { Velmi } \\
\text { vysoká }\end{array}$ & Vysoká & Nízká & Žádná & $\begin{array}{c}\text { Bez } \\
\text { odpovědi }\end{array}$ \\
\hline Programování a algoritmizace & $0,0 \%$ & $24,6 \%$ & $45,9 \%$ & $29,5 \%$ & $0,0 \%$ \\
\hline Hardware a software počítačů & $0,0 \%$ & $42,1 \%$ & $39,8 \%$ & $12,0 \%$ & $6,1 \%$ \\
\hline Práce s databázemi & $0,0 \%$ & $23,1 \%$ & $41,8 \%$ & $29,5 \%$ & $5,6 \%$ \\
\hline Práce s počítačovou grafikou & $0,0 \%$ & $56,1 \%$ & $27,5 \%$ & $4,4 \%$ & $12,0 \%$ \\
\hline
\end{tabular}




\begin{tabular}{|c|c|c|c|c|c|}
\hline \multirow{2}{*}{ Tematický celek } & \multicolumn{5}{|c|}{ Deklarovaná úroveň znalostí } \\
\cline { 2 - 6 } & $\begin{array}{c}\text { Velmi } \\
\text { vysoká }\end{array}$ & $\begin{array}{c}\text { Velmi } \\
\text { vysoká }\end{array}$ & $\begin{array}{c}\text { Velmi } \\
\text { vysoká }\end{array}$ & $\begin{array}{c}\text { Velmi } \\
\text { vysoká }\end{array}$ & $\begin{array}{c}\text { Velmi } \\
\text { vysoká }\end{array}$ \\
\hline Práce s tabulkovým kalkulátorem & $5,8 \%$ & $20,8 \%$ & $56,7 \%$ & $0,0 \%$ & $16,7 \%$ \\
\hline Práce s textovým editorem & $0,0 \%$ & $43,9 \%$ & $5,3 \%$ & $2,6 \%$ & $48,2 \%$ \\
\hline Práce s dotykovými zařízeními & $0,0 \%$ & $28,4 \%$ & $2,6 \%$ & $1,2 \%$ & $67,8 \%$ \\
\hline Práce s technickými grafickými systémy & $0,0 \%$ & $11,4 \%$ & $48,2 \%$ & $38,0 \%$ & $2,3 \%$ \\
\hline Práce se zvukem a videem & $0,0 \%$ & $27,2 \%$ & $44,7 \%$ & $18,1 \%$ & $9,9 \%$ \\
\hline Robotika a el. stavebnice & $0,0 \%$ & $5,3 \%$ & $27,5 \%$ & $66,4 \%$ & $0,9 \%$ \\
\hline Správa a provoz počítačových sítí & $0,0 \%$ & $22,2 \%$ & $49,4 \%$ & $21,3 \%$ & $7,0 \%$ \\
\hline Vyhledávání a získávání informací na Internetu & $0,0 \%$ & $47,4 \%$ & $3,2 \%$ & $2,0 \%$ & $47,4 \%$ \\
\hline Práce s prezentačními aplikacemi & $0,0 \%$ & $43,3 \%$ & $6,7 \%$ & $1,8 \%$ & $48,2 \%$ \\
\hline Vytváŕení a správa webových stránek & $0,0 \%$ & $20,8 \%$ & $41,5 \%$ & $33,6 \%$ & $4,1 \%$ \\
\hline Správa souború a složek & $0,0 \%$ & $36,0 \%$ & $8,5 \%$ & $2,9 \%$ & $52,6 \%$ \\
\hline
\end{tabular}

Tab. č. 2: Deklarovaná úroveñ znalostí

$\mathrm{Z}$ důvodu maximalizace vypovídací hodnoty pořízených dat byl proveden převod slovních hodnocení na nominální data (Maul, Irribarra \& Wilson, 2016) v této struktuře: odpověd' Velmi vysoká - hodnota 4, odpověd' Vysoká - hodnota 3, odpověd' Nízká hodnota 2 a odpověd’ Žádná - hodnota 1 (položce Bez odpovědi byla přiřazena hodnota 0 , čím byla zachována původní pěti stupňová škála). Tato úprava umožnila výpočet aritmetického průměru hodnocení deklarované míry znalostí žáků u jednotlivých tematických celků, což umožnilo sestavit graf průměrů, který vyjadřuje jejich přesnější a přehlednější vzájemné porovnání. Celá situace je patrná z uvedeného grafu číslo 2.

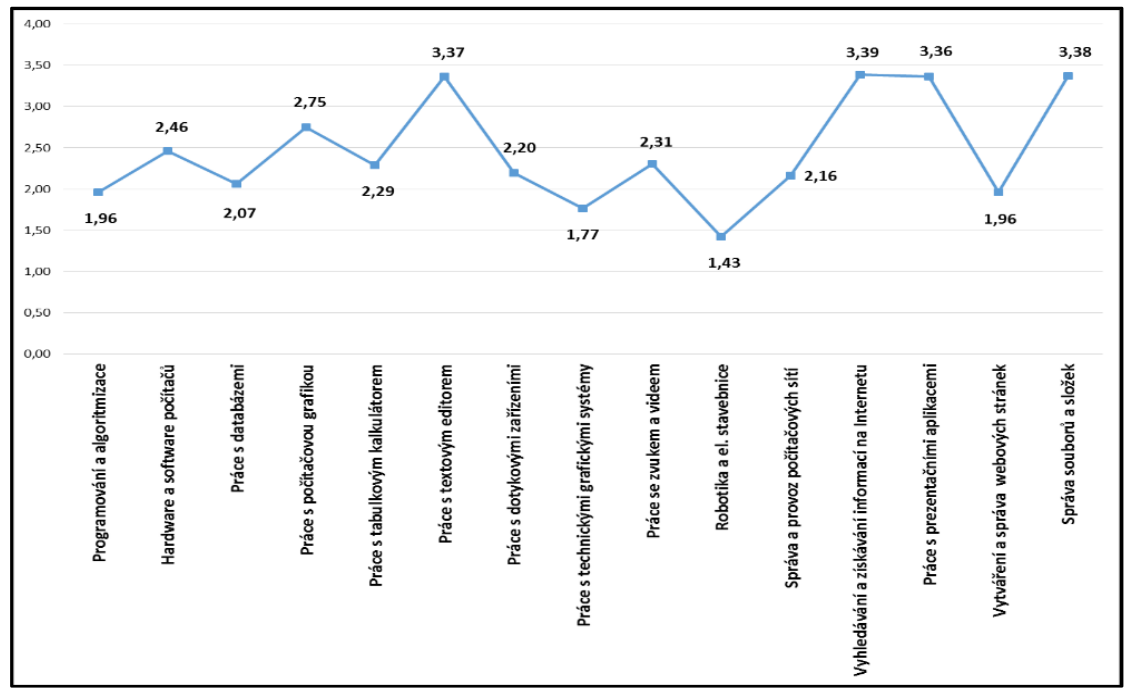

Graf č. 2: Deklarovaná úroveñ znalostí - prüměry

$\mathrm{Z}$ uvedeného grafu 2 vyplývá, že nejvy̌šśí průměrnou míru deklarované úrovně znalostí žáků dosáhly tematické celky: „Práce s počítačovou grafikou“, „Práce s textovým editorem“, „Vyhledávání a získávání informací na Internetu“, „Práce s prezentačními aplikacemi“" a „Správa souborů a složek“. Jedná se o typicky „tradiční“ tematické celky, 
které jsou zahrnuty v rámci RVP pro oblast Informační a komunikační technologie a jejich výuka je tedy logicky nejvíce akcentována. Toto zřejmě není až tak překvapující výsledek, nebot' naplňování témat RVP, která se potom promítají do ŠVP jednotlivých škol, je důsledně kontrolováno v rámci kontrolních návštěv České školní inspekce, a tudíž jsou učitelé nuceni tato témata důsledně vyučovat. Zajímavý je ale fakt, že „,netradiční“ tematické celky jako: „Programování a algoritmizace“, „Práce s databázemi“, „Práce s technickými grafickými systémy“, „Robotika a elektronické stavebnice“ a „Vytváření a správa webových stránek" dosáhly relativně vysokých hodnot. Tuto skutečnost si vysvětlujeme jednak tím, že učitelé v rámci volitelného obsahu RVP tato témata do výuky zařazují, což je potěšující, ale také částečně tím, že samotní žáci se v rámci svých mimoškolních aktivit o tyto témata zajímají a samostatně se v nich vzdělávají.

Zjištěné výsledky byly dále podrobeny dalším analýzám, zaměřeným na skutečnost zda nejsou závislé na jednotlivých signifikantních znacích skupin respondentů. Na základě tohoto tedy byla stanovena následující výzkumná hypotéza $(\mathrm{H} 1)$ a k ní hypotéza nulová $\left(\mathrm{H}_{0,1}\right)$ a alternativní $\left(\mathrm{H}_{\mathrm{A}, 1}\right)$.

H1: Žáci 9. tříd základních škol - chlapci, deklarují vyšší úroveň znalostí v tematických celcích informatiky než žáci 9. tříd základních škol - dívky.

$\mathrm{H}_{0,1}$ : Mezi deklarovanou úrovní znalostí v tematických celcích informatiky, u žáků 9. tříd základních škol - chlapců i dívek, nejsou rozdíly.

$\mathrm{H}_{\mathrm{A}, 1}$ : Žáci 9. tř́́d základních škol - dívky, deklarují vyšší úroveň znalostí v tematických celcích informatiky než žáci 9. tříd základních škol - chlapci.

Stanovená hypotéza byla ověřována na vzorku 342 respondentů, žáků 9. tříd základních škol, pomocí Studentova t-testu pro nezávislé skupiny, přičemž grupovací proměnnou bylo pohlaví respondentů, jak ukazuje tabulka 3 .

\begin{tabular}{|c|c|c|c|c|c|c|c|}
\hline \multirow{2}{*}{$\begin{array}{l}\text { Tematický } \\
\text { celek }\end{array}$} & \multicolumn{7}{|c|}{$\begin{array}{l}\text { t-test; grupováno dle pohlaví, počet respondentů - } \mathbf{3 4 2} \\
\text { Jaká je aktuální úroveň tvých znalostí a dovedností v jednotlivých tématech z } \\
\text { informatiky? }\end{array}$} \\
\hline & $\begin{array}{c}\text { Skup. } 1 \\
\text { dívky }\end{array}$ & $\begin{array}{l}\text { Skup. } 2 \\
\text { chlapci }\end{array}$ & $\mathbf{p}$ & \begin{tabular}{|c|} 
Plat. odp. \\
skup. 1
\end{tabular} & $\begin{array}{c}\text { Plat. odp. } \\
\text { skup. 2 }\end{array}$ & F - poměr & $\begin{array}{c}\text { P - } \\
\text { rozptyl }\end{array}$ \\
\hline Programování a algoritmizace & 1,878788 & 2,048611 & 0,034662 & 198 & 144 & 1,099195 & 0,536912 \\
\hline Hardware a software počítačů & 2,207071 & 2,722222 & $\mathbf{0 , 0 0 0 0 0 1}$ & 198 & 144 & 1,508035 & 0,007628 \\
\hline Práce s databázemi & 1,944444 & 2,187500 & $\mathbf{0 , 0 1 0 1 1 4}$ & 198 & 144 & 1,227243 & 0,183421 \\
\hline Práce s počítačovou grafikou & 2,808081 & 2,687500 & 0,124346 & 198 & 144 & 1,586389 & 0,002723 \\
\hline Práce s tabulkovým kalkulátorem & 2,843434 & 2,840278 & 0,970006 & 198 & 144 & 1,888091 & 0,000037 \\
\hline Práce s textovým editorem & 3,424242 & 3,312500 & 0,149136 & 198 & 144 & 1,110059 & 0,508726 \\
\hline Práce s dotykovými zařízeními & 3,654822 & 3,590278 & 0,325846 & 197 & 144 & 1,012399 & 0,943418 \\
\hline $\begin{array}{c}\text { Práce s technickými grafickými } \\
\text { systémy }\end{array}$ & 1,717172 & 1,822695 & 0,176850 & 198 & 141 & 1,413927 & 0,025257 \\
\hline Práce se zvukem a videem & 2,191919 & 2,423611 & 0,015652 & 198 & 144 & 1,565395 & 0,003605 \\
\hline Robotika a el. stavebnice & 1,297980 & 1,555556 & $\mathbf{0 , 0 0 0 1 7 9}$ & 198 & 144 & 2,273464 & 0,000000 \\
\hline Správa a provoz počítačových sítí & 2,085859 & 2,236111 & 0,100200 & 198 & 144 & 1,174208 & 0,308209 \\
\hline $\begin{array}{c}\text { Vyhledávání a získávání informací } \\
\text { na Internetu }\end{array}$ & 3,439394 & 3,333333 & 0,141988 & 198 & 141 & 1,103331 & 0,523132 \\
\hline Práce s prezentačními aplikacemi & 3,464646 & 3,263889 & $\mathbf{0 , 0 0 7 7 5 2}$ & 198 & 144 & 1,257151 & 0,137179 \\
\hline $\begin{array}{l}\text { Vytváření a správa webových } \\
\text { stránek }\end{array}$ & 1,914141 & 2,006944 & 0,314445 & 198 & 144 & 1,074245 & 0,651895 \\
\hline Správa souborů a složek & 3,419192 & 3,333333 & 0,305268 & 198 & 144 & 1,460573 & 0,013883 \\
\hline
\end{tabular}

Tab. č. 3: Deklarovaná úroveň znalostí vs. pohlaví 
Jelikož hodnota $\mathrm{p}>0,05$ je dosažena pouze u šesti z patnácti tematických celků (Programování a algoritmizace $\mathrm{p}=0,034662$; Hardware a software počítačů $\mathrm{p}=0,000001$; Práce $\mathrm{s}$ databázemi $\mathrm{p}=0,010114$; Práce se zvukem a videem $\mathrm{p}=0,015652$; Robotika a elektronické stavebnice $p=0,000179$; Práce s prezentačními aplikacemi $p=0,007752$ ), nemůžeme celkově nulovou hypotézu odmítnout a je tudíž možné s určitými výhradami konstatovat, že mezi deklarovanou úrovní znalostí v tematických celcích informatiky, u žákủ 9. tříd základních škol - chlapců i divek, nejsou celkové rozdíly a zjištěné výsledky tedy nejsou závislé na pohlaví.

Opět můžeme poukázat na jednu zajímavou souvislost, spočívající v tom, že mezi šesti částečně závislými tematickými celky je celkem pět „netradičních“ tematických celků, které nejsou zahrnuty v rámci RVP pro oblast Informační a komunikační technologie. Jediné „tradiční“ téma zahrnuté mezi těmito položkami je „Práce s prezentačními aplikacemi“", kde dívky deklarují statisticky významně vyšší úroveň znalostí než chlapci. U ostatních „,netradičních“ tematických celkủ, kde je statisticky významný rozdíl, vyšší úroveň znalostí deklarují naopak chlapci.

Pro zjednodušení byla celá situace opět vizualizována do podoby grafu aritmetických průměru hodnocení deklarované míry znalostí žáků u jednotlivých tematických celků, kdy jedna křivka odpovídá hodnocení skupiny děvčat a druhá skupiny chlapců. Celá situace je patrná z uvedeného grafu číslo 3.

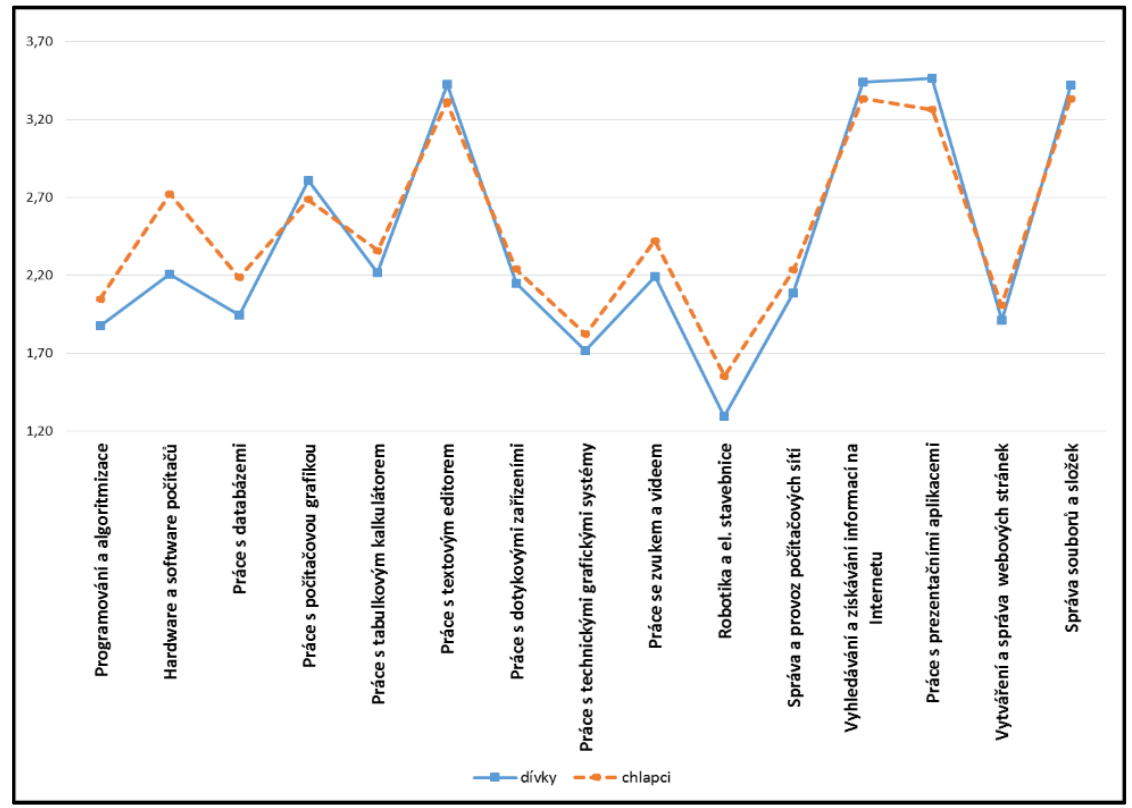

Graf č. 3: Deklarovaná úroveñ znalostí - prüměry dle pohlaví

Na základě provedených analýz je možné konstatovat, že námi stanovený výzkumný předpoklad se podařilo ověřit a zpřesnit: žáci 9. tříd základnich škol deklarují, že nejvyšší úroveň znalostí dosahuji v tematických celcích, které odpovidaji aktuálnímu zaměreni RVP 
pro oblast Informačni a komunikačni technologie. Nejvyšši miru znalostí tak žáci 9. tříd deklaruji v tematických celcich: „Práce s počitačovou grafikou“, „Práce s textovým editorem“, „Vyhledávání a ziskávání informací na Internetu“, „Práce s prezentačnimi aplikacemi “ a „Správa souborů a složek", přičemž tyto výsledky v zásadě nezávisí na pohlaví.

\section{Diskuze a intepretace výsledku}

Zjištěný výsledek není až tak překvapující, nebot' naplňování témat RVP, která se potom promítají do ŠVP jednotlivých škol, je důsledně kontrolováno v rámci kontrolních návštěv České školní inspekce, a tudíž jsou učitelé nuceni tato témata důsledně vyučovat. Toto je také zřejmě důvod, proč žáci u těchto „tradičních“ tematických celků deklarují vyšší míru znalostí než u celků jiných. Zde musíme opět upozornit na skutečnost, že míru svých znalostí posuzovali samotní žáci subjektivně, což mohlo vést ke zkreslení skutečné úrovně znalostí, nebot' je možné že žáci záměrně či nezáměrně snižovali či zvyšovali deklarovanou úroveň svých znalostí.

Zajímavý je ale fakt, že „netradiční“ tematické celky jako: „Programování a algoritmizace“, „Práce s databázemi“, „Práce stechnickými grafickými systémy“, „Robotika a elektronické stavebnice“ a „Vytváření a správa webových stránek“ dosáhly relativně vysokých hodnot. Tuto skutečnost si vysvětlujeme jednak tím, že učitelé v rámci volitelného obsahu RVP tato témata do výuky zařazují, což je potěšující, ale také částečně tím, že samotní žáci se v rámci svých mimoškolních aktivit o tyto témata zajímají a samostatně se v nich vzdělávají. Potřeba celoživotního vzdělávání je dnes nutností a je potěšující, že žáci, byt' v oblasti jim blízké (např. koncept digitálních domorodců, Prensky, 2009 apod.), jsou schopni tohoto již v tak relativně nízkém věku. I když může být toto tvrzení považováno za čirou spekulaci, kterou nelze opř́t o žádná relevantní data, jsme přesvědčeni, že tato myšlenka má reálný základ. Ten vychází především z osobní zkušenosti téměř každého rodiče teenagera, který jistě potvrdí, s jakou rychlostí jsou schopni pronikat do nových technologií a využití nových zařízení v okamžiku, kdy je to opravdu zaujme a chtějí se prezentovat před svými kamarády, třeba i v rámci sociálních sítí (např. fenomén tzv. youtuberů apod.).

\section{Závěr}

Jak bylo uvedeno v úvodu této stati, základním cílem realizovaného výzkumného šetření bylo, na základě relevantních výzkumných metod poznat a popsat aktuálni stav, strukturu, úroveñ digitálnich kompetenci z pohledu žáků 9. tříd základnich škol. V rámci plnění tohoto cíle bylo potřebné provést explanaci názorů žáků na jednotlivé tematické celky vyučované v rámci informatických předmètù. Bylo tedy nutné realizovat několik kroků, spočívajících v dosahování dílčích cílů pro jednotlivé části realizovaného výzkumného šetření. Na základě uvedených výsledků je možné konstatovat, že námi stanovené výzkumné předpoklady a hypotézy se do značné míry potvrdili a je tedy možné konstatovat, že žáci 9. tř́d základnich škol deklaruji, že nejvyšši úroveň znalostí dosahuji $v$ tematických celcich, které odpovidaji aktuálnimu zaměreni RVP pro oblast Informačni a komunikačni technologie, ale deklarují znalosti i v tematických celcich, které jsou nad rámec $R V P$ pro danou oblast.

Na základě zpracování pořízených výzkumných dat je tedy možné vymezit hlavní výstupy realizovaného výzkumného šetření, a to v jednotlivých oblastech, které vyplynuly ze statistického zpracování pomocí metod pedagogického výzkumu. Žáci 9. tř́d 
základnich škol deklarují, že nejvyšši úroveñ znalostí dosahují v tematických celcich, které odpovidaji aktuálnímu zaměreni RVP pro oblast Informačni a komunikační technologie. Nejvyšši míru znalostí tak žáci 9. tř́d deklaruji v tematických celcích: „Práce s počitačovou grafikou “(56,10\%), ,,Práce s textovým editorem “ (43,90\%), ,Vyhledávání a ziskávání informací na Internetu“ (47,40\%), „Práce s prezentačními aplikacemi “ $(43,30 \%)$ a „Správa souborů a složek“ (42,10\%.). Tyto výsledky v zásadě nezávisí na pohlaví a tudíž dívky i chlapci hodnotí subjektivně svou úroveň znalostí bez výrazných statistických rozdílů.

\section{Literatura}

Ala-Mutka, K. (2011). Mapping digital competence: towards a conceptual understanding. Luxembourg: Publications Office of the European Union. Dostupné z http://ftp.jrc.es/ EURdoc/JRC67075_TN.pdf

CSTA. K-12 Computer Science Standards. [online]. 2011. Dostupné z: http://www.csta.acm.org/Curriculum/sub/CurrFiles/CSTA_K-12_CSS.pdf

European Commission (2013). Opening up education: Innovative teaching and learning for all through new technologies and open educational resources. Brussels: Commision of Europian Communities. Dostupné na: http://ec.europa.eu/education/news/doc/openingcom_en.pdf

Ferrari, A. (2013). DIGCOMP: A framework for developing and understanding digital competence in Europe. Luxemburg: Europion Commition. Dostupné na: http://ftp.jrc.es/EURdoc/JRC83167.pdf

Gavora, P. (2010). Úvod do pedagogického výzkumu. Brno: Paido. $261 \mathrm{~s}$.

Chráska, M. \& Kočvarová, I. (2015). Kvantitativní metody sběru dat v pedagogických výzkumech. Zlín: Univerzita Tomáše Bati ve Zlíně, Fakulta humanitních studií. $132 \mathrm{~s}$.

Chráska, M. \& Kočvarová, I. (2015). Kvantitativní metody sběru dat v pedagogických výzkumech. Zlín: Univerzita Tomáše Bati ve Zlíně, Fakulta humanitních studií. $132 \mathrm{~s}$.

Klement, M., Dostál, J. \& Bártek, K. (2017). Perception and Possibilities of ICT Tools in the Education from the Teachers' Perspective. Olomouc - EU: Palacký University, doi: 10.5507/pdf.17.24450933, $241 \mathrm{p}$.

Lessner, D. (2014). Jak si přeložíme „computational thining“. [online]. Dostupné na: http://bit.ly/1qSnJ4X

Maul, A., Irribarra, D.T., \& Wilson, M. (2016). On the philosophical foundations of psychological measurement. Measurement 79, 311-320.

MŠMT. (2014a). Strategie vzdělávaci politiky České republiky ro roku 2020. Dostupné na: http://www.msmt.cz/file/34429 11

MŠMMT. (2014b). Strategie digitálního vzdělávání do roku 2020. Dostupné na: http://www.msmt.cz/vzdelavani/skolstvi-v-cr/strategie-digitalniho-vzdelavani-do-roku-

$\underline{2020}$

MŠMT. (2017). Rámcový vzdělávaci program pro základni vzdělávání. Praha. Dostupné na: http://www.msmt.cz/file/43792 1 1/ RVP ZV 2017 červen.pdf

Prensky, M. (2009). Homo Sapiens Digital: From Digital Immigrants and Digital Natives to Digital Wisdom. Innovate 5(3),. Dostupné z: http://www.innovateonline.info/pdf/vol5_issue3/H._Sapiens_Digital_From_Digital_Imm igrants_and_Digital_Natives_to_Digital_Wisdom.pdf

Rada Evropské Unie. (2011). Závěry rady o úloze vzděláváni a odborné př́pravy při prováděni strategie Evropa 2020. Dostupné na: http://bit.ly/1p4qF8U 
Rambousek, V., \& kol. (2013). Rozvoj informačně technologických kompetencí na základnich školách. Univerzita Karlova, Pedagogická fakulta UK, Dopravní fakulta ČVUT. Praha: České vysoké učení technické.

Rambousek, V., Štípek, J., \& Wildová, R. (2015). ICT competencies and their development in primary and lower secondary schools in the Czech Republic. 5th ICEEPSY International Conference on Education \& Educational Psychology. Procedia-Social and Behavioral Sciences (s. 535-542). Istanbul: Turkey.

Strnad, M. (2015). Přrenositelnost transformace ICT výuky na 2. stupni v Anglii do českých podminek. Nepublikovaná diplomová práce. Praha: Univerzita Karlova.

Štípek, J., Rambousek, V. \& Vaňková, P. (2015). Vybrané výsledky výzkumu rozvoje digitálních kompetencí žáků na ZŠ. Pedagogika, roč. 65, č. 3, 2015, s. 259-273. ISSN 0031- 3815.

The Royal Society. (2012). Shutdown or restart?: The way forward for computing in UK schools. Education Section. London. [online]. Dostupné z: https://royalsociety.org/ /media/education/computing-in-schools/2012-01-12-computingin-schools.pdf

Tupý, J. (2014). Tvorba kurikulárnich dokumentů v České republice: historicko-analytický pohled na prípravu kurikulárnich dokumentů pro základni vzděláváni v letech 1989-2013. Brno: Masarykova univerzita.

Walterová, E. \& kol. (2004). Úloha školy v rozvoji vzdělanosti, 1. a 2. díl. Brno: Paido. 